\title{
OPINIONS ON THE CRITERIA OF A CREATIVE PRODUCT IN FASHION DESIGN
}

\author{
Esra VAROL \\ * Dr. Öğr. Üyesi, Anadolu Üniversitesi,evarol@anadolu.edu.tr
}

\begin{abstract}
Anahtar kelimeler: design, fashion design, creativity, creative product

One of the main purposes of design education is to train creative designers who can design creative products. As it is the case in every field of design, courses offered in all levels in the field of design education also serve to develop and teach creativity, too. This study was conducted to provide a definition of creative product by discussing the opinions of students studying at the Department of Fashion Design at Anadolu University's Faculty of Architecture and Design about the characteristics of a creative product. Interviews were conducted with fourth-year students, designer candidates, in order to collect data. Findings obtained through descriptive analysis were presented in line with the purpose of the study. According to the results of the study, some of the main characteristics of a creative product are originality, newness-novelty, being surprising and production quality.
\end{abstract}

\section{MODA TASARIMINDA YARATICI BİR ÜRÜNÜN ÖLÇÜTLERIINE YÖNELIIK GÖRÜŞLER}

\author{
ÖZ
}

Keywords: tasarım, moda tasarimi, yaratıcilik, yaratıcl ürün
Tasarım eğitiminin başlıca amaçlarından bir tanesi, yaratıcı ürünler tasarlayabilen yaratıcı tasarımcılar yetiştirmektir. Her tasarım alanında olduğu gibi moda tasarımı alanında da eğitimin her düzeyinde yer alan dersler, yaratıcılığın geliştirilmesine ve öğretilmesine hizmet etmektedir. Bu araştırma, Anadolu Üniversitesi, Mimarlık ve Tasarım Fakültesi, Moda Tasarımı Bölümü öğrencilerinin yaratıcı ürünün ölçütlerine yönelik görüşlerini ele alarak yaratıcı ürün tanımının oluşturulması amacı ile hazırlanmıştır. Araştırma verilerinin toplanmasında, tasarımcı adayı olarak dördüncü sınıf öğrencileri ile görüşmeler yapılmıştır. Bu görüşmelerin betimsel analizi ile ulaşılan bulgular araştırma amacı doğrultusunda sunulmuştur. Araştırmada ulaşılan sonuçlara göre yaratıcı ürünün başlıca ölçütlerinden bazıları, özgünlük, yenilik-farklılık, şaşırtıcılık ve üretim kalitesidir. 


\section{Introduction}

Unlike art such as painting or sculpture, design is a purposeful process of visual creation (Wong, 1993: 41). According to another definition, design is made up two things, the process and the product. As a process, design means the planning and organization in reaching a goal and the struggle to be successful in achieving a specific objective. As a product, design is an end, however, as a result, it is an object, an output of a plan or process and an intentional organization. As process and product, design includes everything intentionally created by people (Davis, 1987:1).

As one of the design fields, fashion design means to think and to make visible what is thought. In the production of a fashionable clothing, design is the tool and the clothing is the goal (Aydin and Cakar 1993:268). Fashion designer is the one who makes use of the design tool and ensures that the clothing reaches its goal. Producing products in fashion design or other design fields, the designer is an innovative and creative person who starts change, makes visions come true and creates ideas (Mozota, 2006:17).

These innovative and creative people are trained in fashion design education. In design education, students' specific abilities which they are assumed to have are turned into design skills through a number of concepts made up of techniques, concepts and teachings (Denel, 1981:11). In a comprehensive fashion design program, some of the main subjects are drawing and illustration, design elements and principles, clothing production and technology, computer-based design, marketing and business awareness, fashion and visual culture awareness, presentation and communication techniques, fashion and art history. Courses provided to the students in the fashion design program is determined in line with these subjects (Jones, 2009:12).

Creativity, especially in design education, is a characteristic expected from the designer and it is a concept that is being measured or tried to be measured. In terms of measuring creativity and defining creative product, while some studies discuss how product and process should be discussed together, some studies discuss dimensions of creativity such as product, process, human or environment (Hennessy 1994:193-208; Casakin 2007:21-33; Hasirci and Demirkan, 200317-41; Hasirci and Demirkan 2007:259-271; Demirkan and Hasirci, 2009:294-301; Harpe et al. 2009:37-51). In addition, some studies focus on product creativity with its various aspects (Besemer, 1998: 333-346; Besemer and O'Quin, 1999:287-296; Kidd and Workman, 1999:58-64; Christiaans, 2002:41-54; Horng and Lin, 200954-63; Var- ol, 2010).

When all the related studies are taken into consideration, product is one of the important dimensions in the measurement and evaluation of a creative performance. One of the most significant criteria of performance quality in design and art is the product's creativity (Christiaans, 2002:41). Nevertheless, creativity is also one of the most difficult psychological concepts to explain and measure. According to Baron (1965), although people have ideas about what is creative and what is not, only a few of them can adequately describe what makes an object creative (Kidd and Workman, 1999:58).

Cited by Horng and Lin (2009), Amabile (1983) states that creativity can be described only by product and observed behavior. Other studies discussing the measurement of creative product performance in relation to various subjects were conducted in the field of architecture and industrial product design. The most adopted method in measuring creative product performance in these studies was developed by Bessemer (Horng and Lin, 2009:55). In the respective studies conducted by Bessemer (1998), and Bessemer and O'Quin (1999), the performance criteria for three-dimensional products were approached under three dimensions. These dimensions are novelty, resolution, and elaboration and synthesis. Novelty is about the novelty of product's different qualities. These novelties can be conceptual novelty, using different materials in the preparation of products and using the process or the materials in a new way. Even though the novelty criterion is about these, there are no limits in novelty. Resolution is about the product doing what it promised to do. To put it in a different way, resolution is about the product being functional. For instance, a chair should be sit-on-able. Elaboration and synthesis is about the dimension called style. It refers to the aesthetics of the product. Under these three dimensions, there are nine sub-dimensions (Besemer,1998:334-335; Besemer and O'Quin, 1999: 287288). These dimensions and sub-dimensions are as follows:

Novelty: Originality, Surprising standable

Resolution: Valuable, Logical, Useful, Under-

Elaboration and Synthesis: Organic, Elegant, Well-Crafted

Casakin (2007) defined the creative product criteria as the design product's functionality, novelty, aesthetics, elaborateness, practicability, association with the brief and value (Casakin, 2007:27). Christiaans 
(2002) put forth creativity, technical quality, attractiveness, interest, expressiveness, integrating capacity and goodness of example as the performance criteria for product creativity. In this study, Besemer and O'Quin's CPSS was used (Christiaans,2002:43). In measurement of product performance in the architecture, Demirkan and Hasirci (2009) addressed performance criteria under four dimensions, product's creativity, design elements, design principles and dimensional quality in architecture. Value, appropriateness, flexibility, fluency, novelty, originality, elaboration, redefinition, ability to meet needs and evolution are listed as sub-dimensions under the creativity criterion. While line, color, form, space, light and texture are the sub-dimensions of design elements dimension, repetition, diversity, integrity and harmony are the sub-dimensions of design principles dimension (Demirkan ve Hasirci, 2009: 295-296).

In addition, in fashion design, Varol (2010) determined the creative product's characteristics in fashion design as appropriateness to the theme, appropriateness to target audience, originality, novelty, aesthetics, production quality, appropriateness to the collection logic, functionality and appropriateness to the industrial production (Varol,2010:120-121).

When the studies conducted are considered, it is seen that similar characteristics are used in measuring creative product performance but also different characteristics are used in different fields. Each researcher addressed the subject within the framework of their own expertise area and tried to come up with criteria appropriate for the designs produced in their own fields. When the characteristics are examined generally, it can be said that the common criteria of product performance in design are criteria such as creativity, novelty, originality, aesthetics and functionality.

This study was conducted in order to offer a definition for creative product by discussing fashion design students' views on the characteristics of creative product.

In the literature survey, only several studies on creative product criteria in fashion design were found around the world. Also, in related literature in Turkey there is one research related to subject of this research. These emphasize the importance of the study. It is believed that the study will be beneficial to a great extent to the researchers working on the subject, academicians, students and interested people.

\section{Method}

Because of the way the study research problem and sample group was determined, data collection tools used and the descriptive analysis of the collected data, this study is a qualitative one (Yildirim and Simsek, 2006:81-90). The study sample is made up of fourth-year students who were attending the Department of Fashion Design of Anadolu University's Faculty of Architecture and Design. Criterion sampling method was used for determining the study sample. The basic understanding behind criterion sampling is to collect data from a predetermined sample meeting the criteria (Yildirim and Simsek, 2006:112). The criteria used in determining the students used in the study sample are as follows:

- As a designer candidate, the student should be a fourth-year student in the Department of Fashion Design.

- The student should be willing to be interviewed.

- Student should accept the use of voice recorder for the interview.

The study was conducted during the Autumn semester of 2016-2017 academic year. First, a literature review was performed for the collection of study data. After literature review, an interview form was developed. In line with the research problem and purpose of it, this interview form includes one question and its probes about the characteristics of a creative product. An average of 4.5 minute-interviews were conducted with 21 students who meet the study criteria.

The interviews were recorded with a voice recorder. For collection of the study data, interviews initially were written down as an approximately 19-page report (handwritten). After, descriptive analysis was performed to solve the study problem and reach findings by examining this report. The descriptive analysis was enriched with sample dialogues and presented in line with the questions in the interview.

\section{Findings and Interpretation}

Findings reached at the end of the interviews' descriptive analysis and their interpretations are presented in this section. The questions, developed in line with the study problem and purpose, and the descriptive analysis of the data collected through the probes are as follows:

Explaining the characteristics of a creative product is quite difficult. The students who participated in the study tried to explain these characteristics using their own words with the help of the probes. As a result of the descriptive analysis of the data collected from 
the students, it was found that in general, criteria for a creative product in fashion design are originality, being surprising, aesthetics, appropriateness to the theme, new-novelty and production quality. Providing examples from the students' statements, each characteristic of a creative product is discussed below under related themes.

\section{Originality}

The main characteristic for creativity given by all the students is originality. Originality is defined differently by students. According to the 11 students in the sample, originality is defined as a fingerprint, something that is unique to the person and different from others. In other words, originality is described as belonging to the designer, reflecting the designer's style and the designer's contribution to the product. Examples regarding this subject are as follows:

Interviewer 18: "Creative product is original. I think, originality is unique to the person. The products with the person's signature are original".

Interviewer 4: “... We need to have a line. We need to have a design line. The difference of this design line from other students and designers goes through originality".

Interviewer 2: "The first thing to look for is originality. For me, originality means, when I do and design something, it carries something from me. ... But not individual, as if in general it should be the only one".

Interviewer 13: "If it has to be creative, I think it has to be original. ... If it is not original, it is done before. Then, this is not creativity, it is a little bit of copying. Originality is unique to that person, it shouldn't be tried before, it should be different than what everybody did".

Other students interpreted originality as the product being different than the likes thereof. Examples regarding this subject are as follows:

Interviewer 19: I look at the original one first. I mean, it has to have an original style. I can say that originality means not to look like others".

Interviewer 6: "Actually, the most important thing is originality. ... I mean, we follow fashion now because we are all fashion students. I think, the products that really strike us, that don't look like others are original".

According to ADC-LTSN Learning and Teaching Fund Project: Affective Assessment in Art and Design (2002), originality is discussed under three different categories. These categories are individual originality, relative originality and historic originality. Individual originality refers to a work being unique in relation to one's own works and products. Relative originality refers to a work or product being original among the works and products of the groups the designer is in. Finally, historic originality refers to a work or product being original among all the other works in a specific field (p.7). Upon examining the findings of the students' views provided above, it can be said that students discussed originality sought in fashion design using all the originality categories.

When all the findings are considered, originality can be defined as the power to give idea about how the design is different from others with its characteristics (texture, color, style, etc.) as a whole and in the details and in what way the design belongs to the designer. It is also believed that originality as a characteristic can be discussed under creativity.

\section{Surprising}

The design being surprising is another creativity criterion determined by 19 of the students. Example statements regarding this criterion are as follows:

Interviewer 10: "It surprises. I would say WOW! I get really surprised and excited".

Interviewer 12: "I mean, if it is original and it is something that was never seen before, I get surprised. I wonder somebody thought this. I wonder how it didn't come to my mind. Yes, because of this, it surprises".

Interviewer 3: "Creative product surprises. I mean, instead of a normal shirt, you know when I see something on social media, I look at the screen for a while and I say to myself how did this man come up with this, where did he find this. Creativity is not just about the form. New fabrics are being sewed, they mix so many things inside them. They make the fabric functional. These surprise me, too".

When all the findings are examined, being surprising can be defined as the product being amazing to the people with its all characteristics (form, color, texture, etc.). It is also believed that it can be considered a characteristic of a creative product. In their studies, Besemer (1998), and Besemer and O'Quin (1999) discussed being surprising under novelty, which was under 
the main criterion of creativity (Besemer,1998: 334-335; Besemer and O'Quin, 1999: 287-288).

\section{New-Novelty}

Seventeen of the students participating in the study stated that the product should be new and novel. Example statements regarding this criterion are as follows:

Interviewer 1: "I would say that creativity is to make something that already exists or that doesn't exist reusable by renewing it. Novelty is like this, too".

Interviewer 2: "I would like to see something different, something that wasn't tried before. It can be anything, stitching, fabric, texture. I mean, I would like to see something new in the design".

Interviewer 9: "I think it needs to be different from the things we see. I think this is the first thing that attracts attention. After we perceive visually, we can dive into the details. Who was the product stitched? Maybe the product looks normal but different things were used in its stitching. A new method might be used. I think this is creative".

When the findings related to this characteristic are examined, it is seen that students stated that the product's visual characteristics like color, texture, form, trimmings used and the production techniques like model, pattern, stitching should be different entirely or in detail level. According to Casakin (2007), products and solutions brought to the design problems being different and novel is the most powerful factor in the evaluation of creativity (p.32).

\section{Aesthetics}

Fourteen of the students participating in the study believe that a creative product in fashion design should be aesthetic. Example statements regarding this criterion are as follows:

Interviewer 2: "I look at the product in its entirety. I look at its balance. It should look appealing. Even if I don't know anything about it, it should look nice...".

Interviewer 3: "... It should also look aesthetic. I mean, the colors need to be in harmony. The fabrics should be in harmony. The texture should be in harmony. All of these should be together. If you can do this, it means that you presented a creative product".
Interviewer 4: “... In a stitched product, I first pay attention to form and pattern and later to the materials and design elements. That means, aesthetics".

Interviewer 20: "Originality comes first in design and design elements are important, too. The balance used and others are important, too. Aesthetics is important...".

Interviewer 21: "Aesthetics. Of course, being aesthetic is important in everything. It is really important in clothes, too. The eye directly perceives it. ... Color is important for me, how the color was toned, how it was chosen. Pattern is important, too. The pattern should be made good. Of course, there is a golden ratio in everything. It is in clothes, too".

The beauty of the product is defined as the appreciation of the design elements (texture, color, silhouette, etc) in line with the use of design principles (emphasis, proportion, balance, etc.). In this sense, in deciding whether a product is aesthetic or not, Tunali (2008) stated that they pay attention to characteristics that are called exterior-stylistic characteristics (p.207). Also, according to Tunali (2002), a design as an industrial product is an aesthetic object even though it would not be called art because it was not produced for only aesthetic concerns and has wearability function and a use value (pp. 60-62).

While most of the participants stated that a creative product should be aesthetic, four students mentioned that aesthetics vary from person to person. Statements regarding this are as follows:

Interviewer 1: "Aesthetics is a relative concept. Aesthetics is relative. For example, just because a person became a brand, for example Alexander McQueen, it doesn't mean that his deigns would be aesthetically appealing to everyone. I mean, designer can make people wear different things and reflect these on people but since there's no accounting for taste, a person will not wear the same design or will try to change it in his/ her way if they don't like the design's color, model or a certain stitch".

Interviewer 11: "Beauty is in the eyes of the beholder. Beauty is a relative concept, so does the beauty of a product".

Similar to the students' views, Tunali (2008) expressed that people's beauty judgments change according to their culture, education and psychological structures. Even though there is a consensus between the 
judgments of beauty, this consensus is not absolute but rather relative (pp. 263-266).

Three of the students participating in the study stated that a non-aesthetic product can also be creative. Example statements regarding this subject are as follows:

Interviewer 10: "It doesn't have to be beautiful. For me, originality means creativity. I mean, creative product is different. Something ugly can sometimes be very creative. This is what I believe".

Interviewer 13: "There is a chance that product may not be aesthetic. Because creativity is different, every design may not be aesthetic. I mean, it may not look beautiful to every person. When it is aesthetic, it doesn't mean it will not be creative but not every creative product is aesthetic".

When all students' views regarding this subject are considered, it can be said that a creative product in fashion design also has to be aesthetic. Due to the nature of the field, non-aesthetic clothing may not be considered creative. However, the aesthetics of a design can be defined as the power to create a visual effect in its entirety or in the details with the use of design elements (line, form, color, texture, detail, trimmingsin line with design principles (proportion, rhythm, balance, emphasis, harmony, entirety). In addition, aesthetics is relative and subjective. Even though stated by a few students, it can be said that a creative design may not be considered beautiful by everyone.

\section{Appropriateness to the Theme}

Assumed to exist in every individual at different level in order to design creative products, creativity is not enough by itself. For this reason, designers need an inspiration source (theme) and a good research to activate their creativity at the beginning phase (Atilgan, 2014:461). During the development of the design thought, inspiration sources or themes help designers in explaining the content, activating the production idea and presentation of designs in the mental process. Everything can be an inspiration source for the designers (Eckert and Stacey, 2000:524-525). Trend foresights guide designers to find inspirations. In addition, fashion shows, exhibitions and even television shows can be inspiration sources for designers. Abstract concepts as well as concrete concepts can be inspiration sources for designers (Atilgan, 2014:468). Nature, art, history, architectural structures, movies, books, fashion magazines, blogs, and economic and social events can be shown as examples for fashion designers' inspirations (Fogg, 2014:505).

Nineteen of the participating students stated that appropriateness to the theme as another characteristic of a creative product and a creative form should be appropriate to the theme in terms of characteristics like form, texture, color, detail and trimmings. Example statements regarding this subject are as follows:

Interviewer 4: "I don't think any product that is not appropriate to the theme is creative. Why did we do it, then? This question comes to my mind because with the theme, creativity comes. Because the design goes through a creation (process) and in creation the most important thing is appropriateness to the theme".

Interviewer 13: “...the design should carry the signs of the path we followed. When we see it, I have to say "wow, it has the signs of this theme, it recreated the theme". With the color, model or textures, the materials used or movement it was inspired from, forms and lines, it should make me feel like this".

Interviewer 17: "it affects creativity. I mean, it is important how much we feed from the theme. Theme is your road map. Your design goes to beautiful places if you put the theme inside you as much as possible or if you adopt it as much as possible".

Interviewer 18: "I look at it in terms of meaning. If it has a theme, how much it is appropriate to the theme? It has to comply with the theme in one way. It fits the theme in terms of color. It affects the designer in terms of subject and pattern. This is how it is appropriate to the theme".

Interviewer 21: “... When we do a job, where do we start from? What motivates you? I mean, of course this will affect where the design will go. Your clothing will be good depending on how well you decide your theme".

When all the findings are considered, with elements like texture, fabric, color, trimmings and production characteristics, a creative design needs to reflect the theme that the designer started from and the designer want to express with visual elements. One of the criterion Lindström (2006) suggested for determining creativity performance of a product in art education for Sweden's National Agency for Education in 1998 is students' visual works telling, in other word, reflecting what they intended (p.56). 


\section{Production Quality}

Twenty of the participating students expressed that a creative design should be produced with good workmanship and that production quality affects the product's creativity. Example statements regarding this subject are as follows:

Interviewer 4: "Actually, creativity continues in every aspect of the design. Creativity continues whether it is in the pattern or in the stitching".

Interviewer 11: "I think it affects creativity. Quality is important. Something with bad quality will not look impressive. For creativity, you know we said it is important to be has to be surprising, original and impressive. If these are important for creativity, I think quality is also important. Quality is also important for creativity".

Interviewer 13: "yes, I think it affects creativity because quality helps us to show some things. If we want a collar to stand, we need to choose the right and quality fabric...".

Interviewer 21: "Production quality is of course important. We shouldn't evaluate creativity one by one. It should be evaluated in its entirety. I mean, the pattern is good, it is aesthetically appealing. We need to look at the product as a whole. The pattern should be good, it should look nice, it should be original. These characteristics are complementary".

When all the findings are taken into account, it can be said that students consider this characteristic a factor in deciding the product's creativity and showing the product's creative characteristics. They consider this characteristic with choosing the appropriate material, preparing patterns and quality of the production techniques. According to Besemer (1998, 2006), how well-crafted the product is a criterion in evaluating a creative product (p.287; p.89). Christiaans (2002) argues that, in many studies, creative performance of products is associated with products' technical quality (p.42).

\section{Functionality}

Nearly half (nine students) of the participating students believe that a creative product needs to be functional. According to students who give importance to functionality, design is an activity done to meet a need for a specific purpose. Some example statements regarding this subject are as follows:

Interviewer 1: "Creative product should be able to meet a physical need. It needs to meet a function because in industrial or fashion sense, everything that is thought to be creative is made for a particular purpose".

Interviewer 4: "I think a design's first characteristic is aesthetics as well as usefulness. I think, a product that doesn't have a function doesn't deserve to be produced because when we look for solutions to problems, when we look for solutions to meet needs (functions), that means we already reached a design".

Interviewer 13: "Product needs to be different while using it but the product being creative or different doesn't mean it can't be used, I mean, it doesn't need to be only a visual beauty. On the contrary, the user should easily use it and it should be beneficial to him".

Interviewer 20: "Actually, another characteristic of a designer is to make people's lives easier, for this reason creative product needs to be functional. Maybe it changes depending on what she does. Depending on she needs, the needs makes the product functional".

Interviewer 21: "If we think about is a creative product can be wearable, it being functional is really important. After all, we will not buy a clothing and just hang it in the closet like an ornament. It should be wearable. A person will carry it, it is important because it will be carried on a body".

When functionality is defined as clothes being worn, taken off and being wearable, some students (seven students) view functionality important for every kind of design (haute couture, experimental, industrial, etc.). Also, when functionality is considered in terms of physical characteristics like notability, ergonomic, long wear and usability, students stated that functionality should not be sought as a criterion of creative product and that attractiveness, visual appreciation and aesthetic functionality can come to the fore. For example, when functionality is defined as ergonomics and usability, it can be a criterion looked for in a mountaineer's clothing. On the other hand, functionality may not be looked for in a fashion show where creation of visual attraction and aesthetic functionality are at the forefront. It is believed that these discussions are caused by the fact that clothes have different functions and physical and aesthetic functionality differ with different types of clothing. This is especially associated with the clothing being ready-to-wear product or a haute couture product. Some example explanations regarding this subject are as follows: 
Interviewer 8: "Actually, this is a little bit different because the purpose is important. If the purpose is to be functional and if a ready-to-wear production is being made, the design will move towards that direction. But generally creative designs are not very functional. At least for me, when the design is original and different, the product becomes more avant-garde and this is not very functional. It is only to be worn once. It is for show".

Interviewer 9: Functionality in clothing may change depending on where the clothing will be worn. For example, if it is a party dress, it doesn't need to be functional, if it is to be worn by a photographer or a mountaineer, the clothing needs to be functional. The clothing will bring beauty to the person wearing it in terms of functionality, it will bring usability to the others in terms of functionality".

Interviewer 14: "I think, functionality changes according to the theme. For example, if the product is for ready-to-wear, of course it has to suitable for daily wear but if the product is an avant-garde work, I think it isn't important that the product is functional or not".

When the findings are examined, it is seen that three students have a completely different view from others on the criterion of functionality of a creative product. According to these students, a creative product is not functional. Also, these students associate design as an aesthetic product with art. Some example statements regarding this subject are as follows:

Interviewer 2: "I think functionality doesn't affect creativity. It depends on what is being told".

Interviewer 11: "I think like this: I mean, an aesthetic product doesn't need to be functional. A creative product doesn't have to be functional".

Interviewer 17: "Actually, no. I mean, if a creative product is categorized as functional, you can produce it as ready-to-wear or you can mass produce it but to be art, to be a design, I think it doesn't have to be functional.

When related findings are examined, it is seen that some (two students) students consider the functionality of a creative product as a product having more than its main function which is wearability. Statements about this are as follows:

\section{Interviewer 5: "I mean, a product should reflect}

different characteristics in terms of use. For example, a clothing can be worn in summer and later it can also be worn in winter or another clothing can turn in a night dress".

Interviewer 16: "It might be functional. I mean, if a clothing can turn into something else and be worn like that, it can be creative for me".

When all findings are examined, another factor in a product being a creative design is its functionality. Design product's aesthetics concerns should not change this fact.

According to Wong (1993), "a good design, in short, is the best possible visual expression of the essence of something, whether this be a message or a product. To do this faithfully and effectively, the designer should look for the best possible way this something can be shaped, made, distributed, used, and related to the environment. His creation should not only be just aesthetic but also functional, while reflected or guiding the taste of the time"( p.41).

\section{Results}

As the case is in every field of design, in fashion design education aims to train creative designers. As designer candidates, $4^{\text {th }}$ year fashion design students develop their creative sides with the courses they have taken until $4^{\text {th }}$ year and design products by bringing creative solutions to the assigned design problems. The aim of this research was to provide a definition for creative design in fashion design by taking $4^{\text {th }}$ year fashion design students' views on the criteria of a creative product and to determine these criteria and their definitions. The results reached by evaluating all the findings are as follows:

Creative product in fashion design is evaluated with the criteria of originality, being surprising, new-novelty, aesthetics, production quality, appropriateness to the theme and functionality, and a product is considered creative based on these criteria (Figure 1).

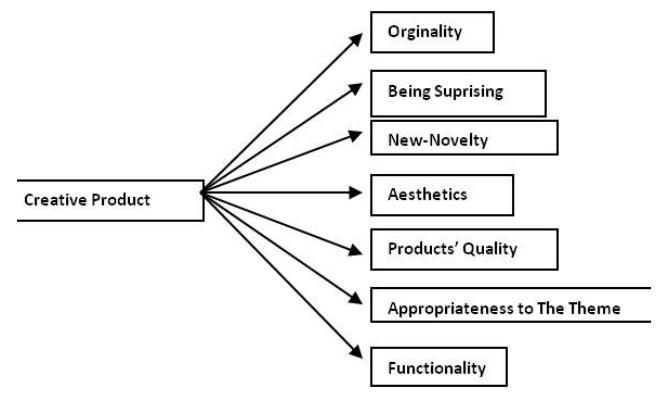

Figure 1:Creative Product Criteria in Fashion Design 
The main characteristic of creativity determined by all the students is the product's originality. Originality of a design is power of the product to be different than others in its entirety and in its details in terms of certain characteristics (texture, color, style, etc.) and the power to give an idea about who the product belongs to. In the field of fashion design, originality sought in a product encompasses all the types of originality (individual, relative, historic).

Another creative product criterion in fashion design is being surprising. Being surprising can be defined as the product being amazing to the people with its all characteristics (form, color, texture, etc.).

When discussing the product's creativity, another criterion to be taken into consideration is new-novelty. This criterion is about the product's visual characteristics like color, texture, form, trimmings used and the production techniques like model, pattern, stitching being different entirely or in detail level.

Another criterion for creative design in fashion design is aesthetics. This criterion can be defined as the appreciation arising from the use of design elements (texture, color, silhouette, etc.) in line with design principles (emphasis, ratio, balance, etc). In addition, aesthetics is a relative and subjective characteristic. It can be said that a creative product may not be found appealing by everybody.

Appropriateness to the theme is another criterion of creative design. Appropriateness to the theme can be defined as the product's power to reflect the message the designer started from and aimed to tell with all the product elements like texture, fabric, color, ornaments and production characteristics.

Fashion design students consider the product's quality as appropriate selection of materials, pattern preparation production techniques' quality, and see it as a criterion in deciding a product's creativity and in showing the designer's creative sides. This criterion can be defined as the materials (fabric, auxiliary material, ornament material) selected for the design to be appropriate to the theme, model, clothing type and purpose of use.

Another factor of a design being creative is its functionality. The physical and aesthetic functionality of a clothing as a fashion design product varies for different clothing types. This criterion can be expressed as the designs' appropriateness to their purpose and usage with their models, colors, textures, accessories, patterns and production techniques.

When all the criteria are taken into consideration, creative product in fashion design can be defined as "designs with characteristics like originality, newness-novelty, functionality, good quality and appropriateness to the theme". It can be said that this definition is similar to the definition of creative product characteristics and criteria in the literature.

\section{REFERENCES}

ADC-LTSN Learning and Teaching Fund Project: Effective Assessment in Art and Design. (2002), Writing Learning Outcomes and Assessment Criteria in Art and Design. [online] London Institute, Available at: <http: / / www.arts.ac.uk> (accessed 15.02.2008).

ATILGAN, D. K. (2014), "Giysi tasarımında esinlenmenin ve arastirmanin yaraticiliga etkisi", International Journal of Social Science, Vol. 27, pp. 461-477.

AYDIN, S. ve CAKAR, G.E. (1993), Cagdas Giysi Tasariminda Oge ve Prensipler, I. Turkiye Hazır Giyim ve Konfeksiyon Kongresi. 1-2 Aralık. Istanbul: Gokha Matbaası.

BESEMER, S. P. (1998), “Creative product analysis matrix: testing the model structure and a comparasion among products-three novel chairs", Creativity Research Journal, Vol. 11 No.4, pp. 333-346.

BESEMER, S. P. and O'Quin, K. (1999), Confirming the three-factor creative product analysis matrix model in an american sample, Creativity Research Journal, Vol. 12, No.4, pp. 287-296.

BESEMER, S. P. (2006), Tarz Çağında Ürünler Yaratma, (Editor: A. Esra Aslan). Morpa Kultur Yayinlari Ltd. St., Istanbul

CASAKIN, H.P. (2007), Methaphors in design problem solving: implications for creativity, International Journal of Design, Vol.1, No.2, pp. 21-33.

CHRISTIAANS, H.H.C.M. (2002), Creativity as a design criterion, Creativity Research Journal, Vol.14, No. 1, pp. 41-54.

DAVIS, M.L. (1987), Visual Design In Dress (Second Edition), Prentice- Hall Inc., USA-New Jersey.

DEMIRBAS, O.O. and DEMIRKAN, H. (2007), Learning styles of design students and the relationship of academic performance and gender in design education, Learning and Instruction, Vol. 17, pp. 345-359.

DEMIRKAN, H. and HASIRCI, D. (2009), Hidden dimensions of creativity elements in design process, Creativity Research Journal, Vol.21, No. 2-3, pp. 294-301. 
DENEL, B. (1981), Temel Tasarım Ve Yaratıcılık, O.D.T.Ü. Mimarlık Fakultesi Basim Isligi, Ankara.

ECKERT, C. and STACEY, M. (2000), Sources of inspiration : a language of design, Design Studies, Vol. 21, pp.523-538.

FOGG, M. (2014), Modanin Tum Oykusu, Hayalperest Yayınevi, Istanbul.

HARPE, de la B., PETERSON, J.F., FRANKHAM, N, ZEHNER, R., NEALE, D., MUSGRAVE, E. and McDERMOTT, R. (2009), Assessment focus in studio: what is most prominent in architecture, art and design?, International Journal of Art and Design Education, Vol.28, No.1, pp. 37-51.

HASIRCI D. and DEMIRKAN H. (2003), Creativity in learning environments: the case of two sixth grade art-rooms. The Journal of Creative Behavior, Vol.37, No. 1, pp. 17-41.

HASIRCI D. and DEMIRKAN H. (2007), Understanding the effects of cognition in creative decision-making: a creativity model for enhancing the design studio process, Creativity Research Journal, Vol.19, No.2, pp. 259-271.

HENNESSEY, B. A. (1994), The conselsual assessment technique: an examination of the relationship between ratings of product and process creativity, Creativity Research Journal, pp.193-208.

HORNG J-S. and LIN, L. (2009), The development of a scale for evaluating creative culinary products, Creativity Research Journal, Vol.21, No. 1, pp. 5463.

JONES, S. J. (2009), Moda Tasarimi, (Translate: Huseyin Kilic), Guncel Yayincilik, Istanbul.

KIDD, L.K. and WORKMAN, J.E. (1999), Assessment of creativity in apparel design, Clothing and Textiles Research Journal, Vol. 17, No.1, pp. 58-64.

LINDSTROM, L. (2006), Creativity: what is it? can you assess it? can it be taught?, International Journal of Art and Design Education, Vol.25, No. 1, pp. 5366.

MOZOTA, Borja De, B. (2006), Tasarim Yonetimi (Translate: Sibel Kacamak), MediaCat Kitaplari, Istanbul.

TUNALI, I. (2002), Tasarim Felsefesine Giris, Yap1 Endustrisi Merkezi Yayinlari, Istanbul.

TUNALI, I. (2008), Estetik. (11. basim), Remzi Kitapevi, Istanbul.

VAROL, E. (2010), Moda Tasarimi Egitiminde Tasarimlarin Degerlendirilmesine Yonelik Bir Olcme Araci Gelistirme, PhD thesis, Gazi Universitesi, Egitim Bilimleri Enstitusu, Giyim Endustrisi ve Moda Tasarimi Egitimi Anabilim Dal1, Ankara, Turkey.
WONG, W. (1993), Principles Of Form And Design, John Wiley \& Sons, Canada.

YILDIRIM, A. ve SIMSEK, H. (2006), Sosyal Bilimlerde Nitel Arastırma Yontemleri, Seckin Yayinlari, Ankara. 